\begin{tabular}{|c|c|c|}
\hline \multirow[b]{2}{*}{$\vec{T}$} & Int.J.Curr.Microbiol.App.Sci (2021) 10(10): 252-258 & \\
\hline & $\begin{array}{l}\text { International Journal of Current Microbiology and Applied Sciences } \\
\text { ISSN: 2319-7706 Volume } \mathbf{1 0} \text { Number } \mathbf{1 0}(\mathbf{2 0 2 1 )} \\
\text { Journal homepage: http://www.ijcmas.com }\end{array}$ & 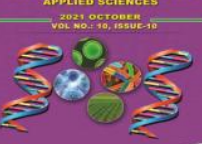 \\
\hline $\begin{array}{l}\text { EXCELLEN T } \\
\text { PUBLISHERS }\end{array}$ & & \\
\hline
\end{tabular}

Original Research Article

https://doi.org/10.20546/ijcmas.2021.1010.030

\title{
Study of Temperature Profile of the Solar Pyramid Dryer
}

\author{
O. S. Karpe*, A. G. Mohod, Y. P. Khandetod, R. T. Thokal and R. M. Dharaskar \\ Department of Electrical and Other Energy Sources, Dr. Balasaheb Sawant Konkan Krushi \\ Vidyapeeth Dapoli, Maharashtra, India \\ *Corresponding author
}

Keywords

Pyramid Dryer,

Temperature

profile, Natural

convection, drying

air

Article Info

Accepted:

10 September 2021

Available Online:

10 October 2021

The experiment was conducted at 'Energy Park', Department of Electrical and Other Energy Sources CAET, Dr. Balasaheb Sawant Konkan Krushi vidyapeeth Dapoli, Dapoli. The readings of temperature inside the dryer has been taken from 9:00 AM TO 5:00 PM with interval of thirty minute. It is recorded that maximum temperature inside the solar pyramid dryer was at 12:00 noon that is $55.5{ }^{\circ} \mathrm{C}$ and corresponding solar radiations where 552 $\mathrm{W} / \mathrm{m}^{2}$.After analysing the temperature pattern from the graphs we can say that the temperature of air inside the dryer at various places varies such that, temperature of air at bottom of dryer was minimum, and it goes on increasing as the air moves from bottom to top of the solar pyramid dryer. Subsequently the maximum temperature found at the exhaust of the solar dryer. The average drying temperature is found to be suitable for drying of fruits and vegetables.

\section{Introduction}

Drying is the most widely used primary method of food preservation. The removal of moisture prevents the growth of the microorganisms responsible for the spoilage of the foods. This can be achieved by drying or dehydration for removal of water form a product. Natural sun drying has been used since time immemorial. In open sun drying the aroma and other volatile chemical compound of medicinal plants are losses due to direct solar radiation and other weather parameters.
Open sun drying also has much limitation. The most common change occurs in the green colour vegetables during the thermal processing is the conversion chlorophyll to the pheophytin, causing a colour change from bright green to olive-brown, which is undesirable to consumer for a green vegetables, pre-treatment and temperature control prior to the drying can aid the chlorophyll retain during the drying operation.

Solar dryers uses solar energy to dry the food by raising the temperature of the air 
surrounding it, in terms increasing circulation of air and moisture removal rate, solar drying not required any conventional (fossil fuels) source of energy, so they are more sustainable in technology and more cost efficient in nature the only requirement of the solar dryers is availability of solar energy and India is being tropical country blessed with abundant of solar energy. The pyramid shaped solar dryers are gaining importance now a days, due their drying characteristics and drying quality.

The drying characteristics and drying quality are the functions of the temperature inside the solar dryer. The pyramid shape is said to have a special effects on food preservation. In order to determine the effect of temperature on food drying inside the solar pyramid dryer, there is need to determine the temperature and its variation at various places inside the pyramid dryer.

\section{Materials and Methods}

The experiment was conducted at Energy Park at Electrical and Other Energy Sources Department, CAET, Dapoli. During study of temperature inside the solar pyramid dryer the following methodology is adopted and the Materials were used:

Solar Pyramid Dryer

Solarimeter

Temperature Data logger

Thermometer

Clock

\section{Technical Details of solar pyramid dryer}

Type: pyramid

Capacity: $5 \mathrm{~kg}$.
No of drying trays: 4 nos.

Total tray area: $2.4 \mathrm{~m}^{2}$

Dimensions: $1.50 \times 1.50 \times 1.54$ meter

Drying temperature: 45 to $60^{\circ} \mathrm{c}$.

Plastic cover: UV stabilized $200 \mu \mathrm{m}$

The solar pyramid dryer was developed and installed at Energy Park is selected for the temperature study. Trays inside the pyramid dryer are removed in order to fix the probes of data logger thermometer inside the dryer. The cross section of pyramid dryer is demarcated such a way that, the temperature sensors are placed equidistance from each other at the central cross section of the dryer, ten number of temperature probes (A B C D E F G H I \& J) are distributed inside the central cross section pyramid as shown in following fig. In above way the temperature probes are tied vertically inside the solar pyramid dryer and the measurements of the temperature are taken with the help of data logger after closing of the loading door of the pyramid dryer. The readings are taken with 30 minutes of the time interval starting from 9:00 AM in the morning up to the 5:00 PM.

\section{Data Recording}

The data recording of the readings is tabulated in the table 2 .

Where A, B, C, D, E, F, G, H, I, and J are the temperatures at the places shown in fig. The sections of the pyramid are divided for temperature analysis in four parts as shown below

\section{Analysis of Data}

The collected temperature and solar radiations is tabulated and analyzed in following way 
The central cross section of the pyramid is divided in to the four parts that are bottom middle, top and exhaust. The average temperature at the four sections is calculated by dividing the number of probes at each section to the sum of the temperatures at the probe at specific time. The graphs of temperatures at various place and solar radiation with respect to time are prepared.

\section{Results and Discussion}

The readings of temperature inside the dryer have been taken from 9:00 AM TO 5:00 PM with interval of thirty minute.

\section{Average temperature}

The average ambient temperature recorded during the test was $36^{\circ} \mathrm{C}$.

Average temperature recorded at the Bottom section of the dryer was $46.63{ }^{\circ} \mathrm{C}$.

Average temperature recorded at the Middle section of the dryer was $47.19^{\circ} \mathrm{C}$.

Average temperature recorded at the Top section of the dryer was $49.86^{\circ} \mathrm{C}$.

Average temperature recorded at the Exhaust/ chimney of the dryer was $49.54{ }^{\circ} \mathrm{C}$.
The overall average temperature inside the pyramid dryer recorded was $48.26^{\circ} \mathrm{C}$.

\section{Maximum and Minimum Temperature}

Maximum and minimum ambient temperatures recorded during the test was $39.7^{\circ} \mathrm{C}$ at $02: 00 \mathrm{PM}$ and $32^{\circ} \mathrm{C}$ at 09:00 $\mathrm{AM}$ respectively.

Maximum and minimum temperatures inside the pyramid dryer recorded during the test was $55.4^{\circ} \mathrm{C}$ at $12: 00$ noon and $36.4^{\circ} \mathrm{C}$ at $05: 00 \mathrm{PM}$ respectively.

Maximum and minimum temperatures at bottom section was $51.05^{\circ} \mathrm{C}$ at $12: 00$ noon and $36.85{ }^{\circ} \mathrm{C}$ at 05:00 PM.

Maximum and minimum temperatures at Middle section was $51.6^{\circ} \mathrm{C}$ at $12: 00$ noon and $36.4{ }^{\circ} \mathrm{C}$ at 05:00 PM.

Maximum and minimum temperatures at Top section was $54.85{ }^{\circ} \mathrm{C}$ at $11: 30 \mathrm{AM}$ and 37.55 ${ }^{\circ} \mathrm{C}$ at 05:00 PM.

Maximum and minimum temperatures at exhaust / chimney section was $55.5{ }^{\circ} \mathrm{C}$ at 12:00 noon and $37.5^{\circ} \mathrm{C}$ at 05:00 PM.

Table.1 Data Recording

\begin{tabular}{|c|c|c|}
\hline Sr. No. & Placement & Temperature probes \\
\hline $\mathbf{1}$ & Bottom & A, B, C, D \\
\hline $\mathbf{2}$ & Middle & E, F, G \\
\hline $\mathbf{3}$ & Top & H, I \\
\hline $\mathbf{4}$ & Exhaust & J \\
\hline
\end{tabular}


Table.2 Average Temperatures at various places

\begin{tabular}{|c|c|c|c|c|c|c|}
\hline Time & $\begin{array}{c}\text { Solar } \\
\text { Raddi. } \\
\left(\mathbf{W} / \mathbf{m}^{2}\right)\end{array}$ & $\begin{array}{c}\text { Amb. } \\
\text { Temp. } \\
\left({ }^{0} \mathrm{C}\right)\end{array}$ & $\begin{array}{c}\text { Bottom } \\
\text { Avg, } \\
\left({ }^{0} \mathrm{C}\right)\end{array}$ & $\begin{array}{c}\text { Middle } \\
\text { Avg. } \\
\left.\text { ( }{ }^{\mathbf{0}} \mathrm{C}\right)\end{array}$ & $\begin{array}{l}\text { Top } \\
\text { Avg } \\
\left({ }^{0} \mathrm{C}\right)\end{array}$ & $\begin{array}{c}\text { Exhaust } \\
\left({ }^{0} \mathrm{C}\right)\end{array}$ \\
\hline 09:00 & 358 & 32 & 44.9 & 45.2 & 49.1 & 47.4 \\
\hline 09:30 & 440 & 33 & 48.5 & 48.9 & 52 & 45.5 \\
\hline 10:00 & 497 & 36.2 & 46.5 & 47.2 & 50.1 & 49.4 \\
\hline 10.30 & 517 & 36.5 & 50.0 & 50.6 & 52.7 & 52 \\
\hline 11:00 & 546 & 37.5 & 48.5 & 48.5 & 51.1 & 50.5 \\
\hline 11.30 & 551 & 36.9 & 50.5 & 50.6 & 54.2 & 55.4 \\
\hline 12:00 & 552 & 38.7 & 51.0 & 51.6 & 54.8 & 55.5 \\
\hline 12.30 & 560 & 38.6 & 49.6 & 50.2 & 53.7 & 54.1 \\
\hline 01:00 & 558 & 38.2 & 47.8 & 48.4 & 51.3 & 51.5 \\
\hline 01:30 & 546 & 38.4 & 49.2 & 49.9 & 53.1 & 52.8 \\
\hline 02:00 & 540 & 38.9 & 49.3 & 49.8 & 53.1 & 52.9 \\
\hline 02:30 & 526 & 39.7 & 48.3 & 48.9 & 51.8 & 52 \\
\hline 03:00 & 487 & 38.6 & 47.4 & 48.1 & 50.8 & 51.1 \\
\hline 03:30 & 428 & 39.8 & 46.1 & 47.1 & 50.3 & 50.4 \\
\hline 04:00 & 319 & 37.3 & 39.7 & 40.0 & 42.5 & 44.9 \\
\hline 04:30 & 300 & 33.2 & 38.0 & 37.6 & 39.3 & 39.3 \\
\hline 05:00 & 280 & 35.3 & 36.8 & 36.4 & 37.5 & 37.5 \\
\hline
\end{tabular}

Fig.1 Solar pyramid dryer Methodology

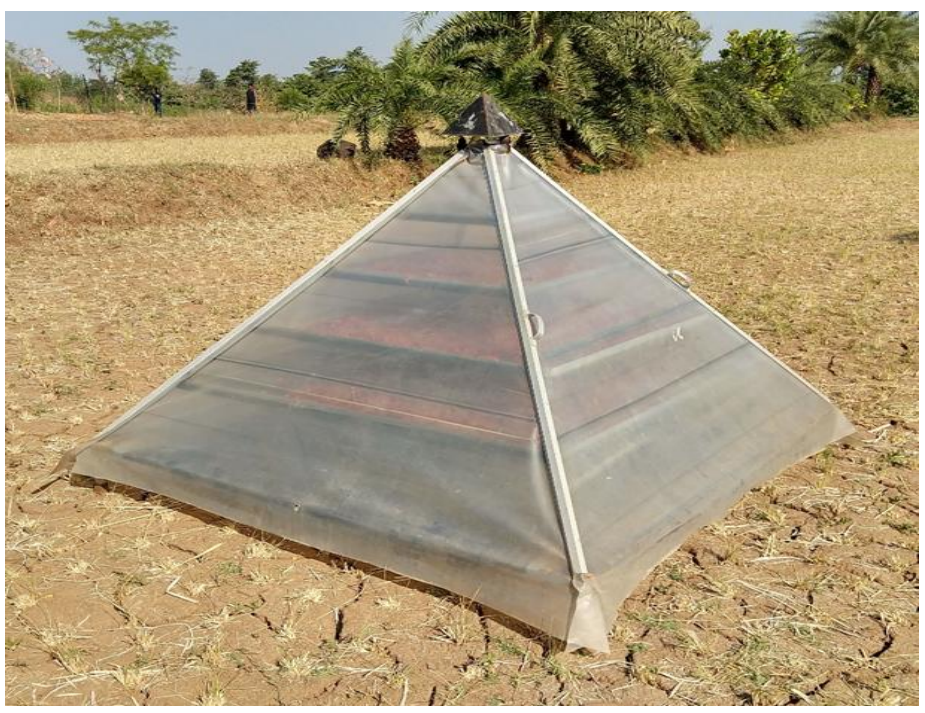


Fig.2 Temperature probes location inside the solar pyramid dryer

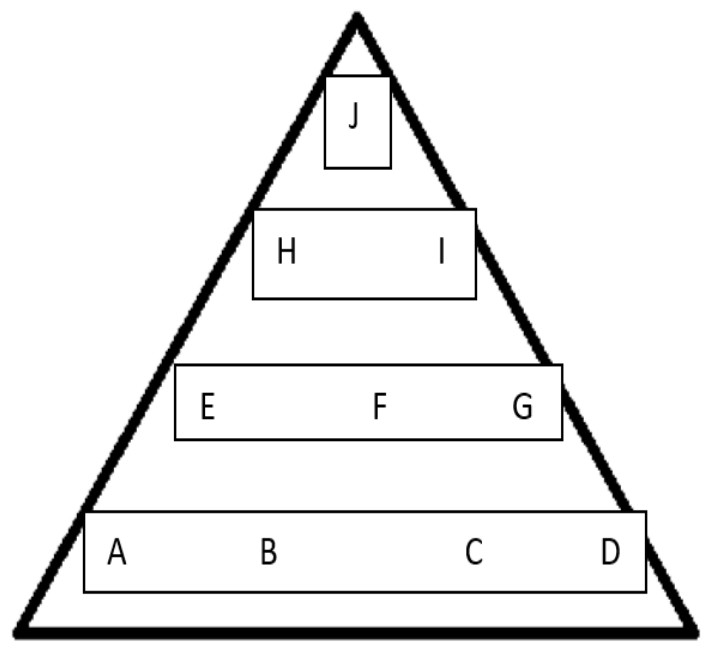

Fig.3 Installation of probes inside the dryer

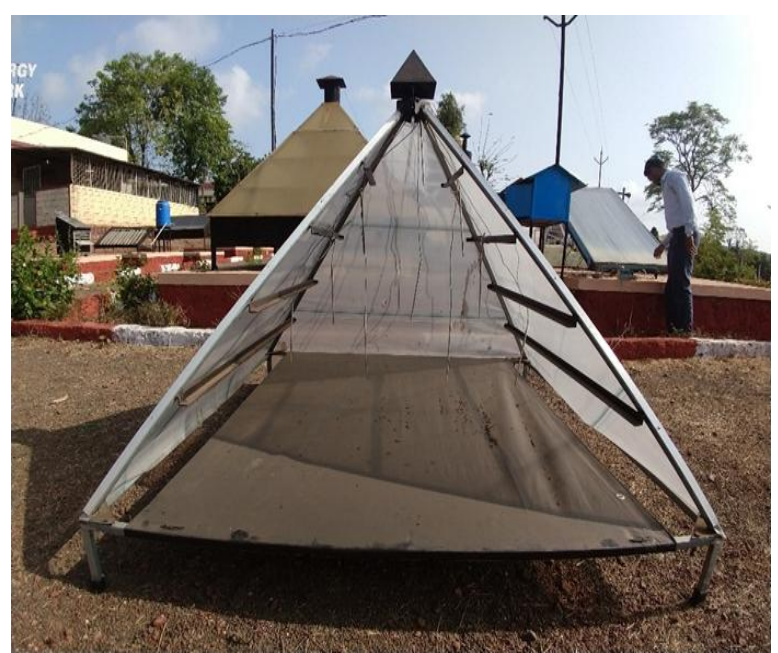

Graph.1 Graphical Representation

Temperatures at various places with respect to time

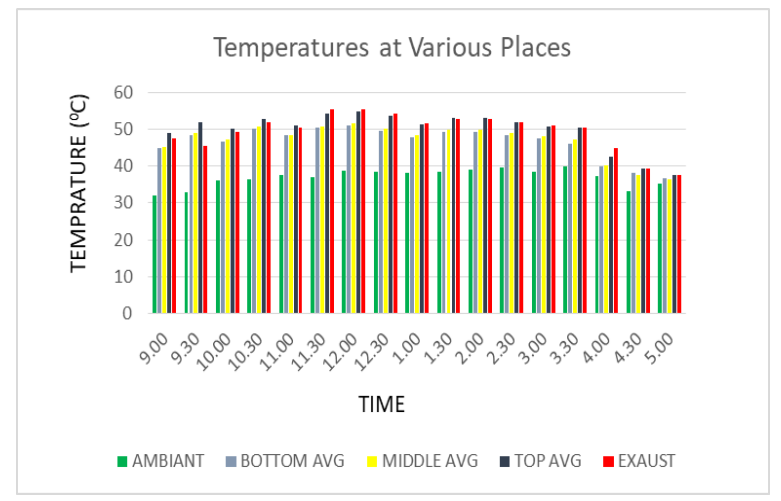


Temperature at various places, solar radiations and time

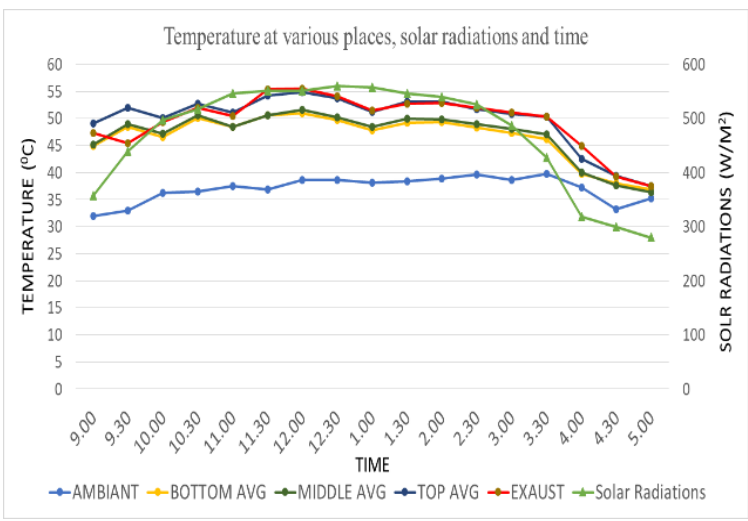

Temperature profile of the pyramid dryer

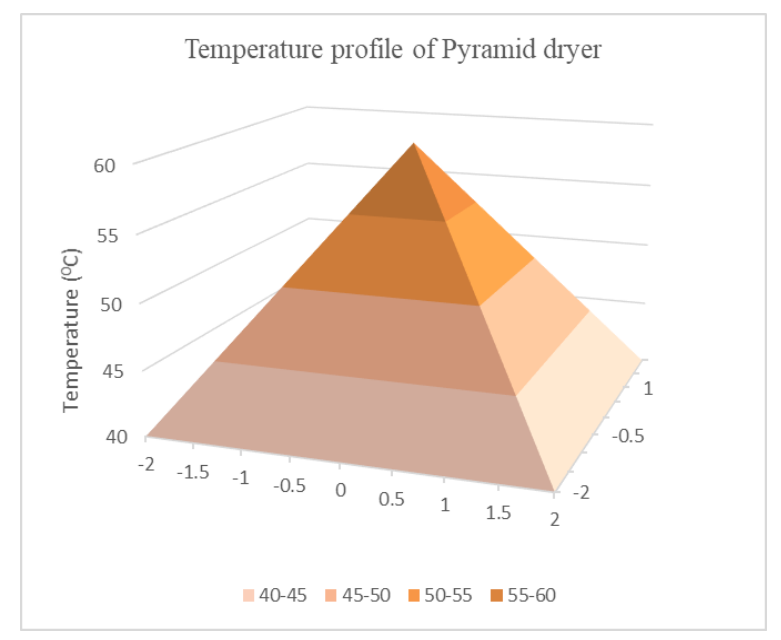

At test, the avg. temperature and relative humidity during daytime in the Pyramid dryer was $48^{\circ} \mathrm{C}$ and 30 per cent and corresponding average ambient temperature was $36^{\circ} \mathrm{C}$.

Maximum temperature recorded inside the pyramid dryer was $55.4^{\circ} \mathrm{C}$ on $12: 00$ noon the corresponding ambient temperature was $38.7^{\circ} \mathrm{C}$ and solar radiations was $552 \mathrm{~W} / \mathrm{m}^{2}$.

Minimum temperature recorded inside the pyramid dryer was $37.55^{\circ} \mathrm{C}$ at 5:00 PM and corresponding ambient temperature was 35.3 ${ }^{\circ} \mathrm{C}$ and the solar radiations was $280 \mathrm{~W} / \mathrm{m}^{2}$.

After analyzing the temperature pattern from the graphs, temperature of air at bottom of dryer was minimum, and it goes on increasing as the air moves from bottom to top of the solar pyramid dryer. Subsequently the maximum temperature found at the exhaust of the solar dryer. The temperature of the drying air was found suitable for drying of fruits and vegetables.

\section{References}

Abhay Lingayat, Chandramohan V. P. and V. R. K. Raju. (2017) Design, Development and Performance of Indirect Type Solar Dryer for Banana Drying, Energy Procedia (109): $409-416$.

Akella A. K., R. P. Saini and M. P. Sharma (2009) Social, economical and 
environmental impacts of renewable energy systems, Renewable Energy (34): 390-396.

Assefa Ayyappan S. and Dr. K. Mayilsamy "Solar Tunnel Drier With Thermal Storage For Drying of opra" Proceedings of the 37th National \& 4th International Conference on Fluid Mechanics and Fluid Power December 16-18, 2010, IIT Madras, Chennai, India.

Bala, B. K., Hussain, M. D. and Mondol, M. R. A. "Experimental Investigation of Solar Tunnel Drier for Drying of Pineapple" Journal of the Institution of Engineers, Bangladesh, Agricultural Engineering Division, 26(4): 37-44 (1999).

Chakraverty, A. (1988). Post-harvest technology of cereals, pulses and oil Seed. New Dehli, Oxford and IBH Pub. Co. Pvt. Ltd., PP. 3339

Ekechukwua O. V. and B. Nortonb (1999) Review of solar-energy drying systems II: an overview of solar drying technology, Energy Conversion \& Management (40): 615-655.

Farid Sayyad, Nilesh Rajendra Sardar, Jaidipsinh Pravinsing Rathod and Brijesh Yaduvanshi, (2015) Design and Development of Solar cooker Cum Dryer, Current World Environment Vol 10: 985993.

Garg, H. P. and Kumar R, 2000. Studies on Semi Cylindrical solar tunnel dryer: thermal performance of collector Applied thermal and engineering. J. Renewable Energy. 20: 115-131.

Mangesh Gavhale, Swapnil Kawale, Ramesh Nagpure, V. N. Mujbaile, N. S. Sawarkar (2015) Design and Development of Solar Seed Dryer, International Journal of Innovative Science, Engineering \& Technology Vol 2: 1005-1010.
Muhammad Zakaria Hossain; M. A. Hossain; Md. Abdul Awal; Md. Masud Alam and A. H. M. Maniruzzaman Rabbani (2015) Design and Development of Solar Dryer for Chilli Drying, International Journal of Research vol 2: 63-78.

Mujau Numbing and Gaius Maikasuwa (2015) Construction of domestic solar fish dryer, IOSR Journal of Applied Physics Vol 7: 913.

Palled, Vijaykumar, S. R. Desai, lokesh and M. Anantachar 2012. Performance evaluation of solar tunnel dryer for chilly drying Karnataka J. Agric. Sci.,25 (4): 472-474

Papade C. V. and M. A. Boda (2014) Design \& Development of Indirect Type Solar Dryer with Energy Storing Material, International Journal of Innovative Research in Advanced Engineering Vol 1: 109-114.

Sagar P. Thombare, Vishal Gunjal and Snehal Bhandarkar (2016) Overview of Renewable Energy in Maharashtra, International Journal of Advanced Research in Computer and Communication Engineering, Vol 5: 200-203.

Snehal Dongardive (2014) Development and Evaluation of Forced Convection Solar Cabinet Dryer M. Tech thesis of Collage of Agricultural engineering and technology Dapoli.

Sonawane V. B., R. S. Saler, M. D. Sonawane, and V. B. Kadam. (2012) Ethnobotanical Studies of Mokhada District Thane, International Journal of Life sciences and farma research. Vol 2: L88-L93.

Vinay Narayan Hegde, Viraj Shrikanth Hosur, Samyukth kumar K Rathod, Puneet A Harsoor and K Badari Narayana (2015) Design, fabrication and performance evaluation of solar dryer for banana, Energy, sustainability and society 1-12.

\section{How to cite this article:}

Karpe, O. S., A. G. Mohod, Y. P. Khandetod, R. T. Thokal and Dharaskar, R. M. 2021. Study of Temperature Profile of the Solar Pyramid Dryer. Int.J.Curr.Microbiol.App.Sci. 10(10): 252258. doi: https://doi.org/10.20546/ijcmas.2021.1010.030 